\title{
Bioavailability of Two Oral Tablet Formulations of citalopram 20 mg: Single-Dose, Open-Label, Randomized, Two-Period Crossover Comparison in Healthy Mexican Adult Subjects
}

\author{
Jose Antonio Palma-Aguirre ${ }^{1 *}$, Lopez-Gamboa Mireya', Castro-Sandoval Teresita de Jesus ${ }^{1}$, \\ Pereda-Girón Mariel'1, Zamora-Bello Elisa', Melchor-Baltazar María de los Angeles', \\ Mendez Carmona Ma Esther ${ }^{1}$, Canales-Gomez Juan Salvador ${ }^{2}$
}

${ }^{1}$ Centro de Estudios Científicos y Clínicos Pharma, S.A. de C.V., Mexico City, Mexico ${ }^{2}$ Productos Medix, S. A. de C. V. Mexico City, Mexico

\begin{abstract}
The aim of this study was to compare the bioavailability and determine the bioequivalence of one test formulation (citalopram $20 \mathrm{mg}$ oral tablet) with its corresponding list reference-drug formulation in Mexico.

A single dose, randomized, open-label, 2-period crossover, post-marketing study with a 2-weeks washout period between doses was conducted. Blood samples were drawn at baseline, $0.5,1.0,2.0,3.0,4.0,5.0,6.0,7.0,8.0$, $10.0,12.0,24.0,48.0,72.0,96.0$ y 120.0 hours after dosing. Citalopram plasma levels were determined using HPLC assay method.

A total of 24 subjects were enrolled in the study. The bioequivalence test drug values were $\mathrm{C}_{\max }$ of $26.37 \mathrm{ng} /$ $\mathrm{mL}, \mathrm{t}_{\max }$ of $3.76 \mathrm{~h}, \mathrm{AUC}_{0-\mathrm{t}}$ of $613.84 \mathrm{~h} . \mathrm{ng} / \mathrm{mL}, \mathrm{AUC}_{0-\infty}$ of $879.65 \mathrm{~h} . \mathrm{ng} / \mathrm{mL}$, and reference drug values of $\mathrm{C}_{\text {max }}$ of 25.50 $\mathrm{ng} / \mathrm{mL}, \mathrm{t}_{\max }$ of $3.96 \mathrm{~h} \mathrm{AUC}_{0-\mathrm{t}}$ of $596.65 \mathrm{~h} . \mathrm{ng} / \mathrm{mL}, \mathrm{AUC}_{0-\infty}$ of $982.38 \mathrm{~h}$. ng/mL. No period or sequence effect was observed.

In this study in healthy Mexican adult subjects, a single dose of citalopram $20 \mathrm{mg}$ of the test formulation was found to be bioequivalent to the corresponding reference formulation according to the regulatory definition of bioequivalence based on the rate and extent of absorption. Both formulations were generally well tolerated.
\end{abstract}

Keywords: Citalopram; Pharmacokinetics; Bioequivalence; Bioavailability; Human; HPLC

\section{Introduction}

Citalopram, 1 - [3 - (dimethylamino)propyl] - 1- (4 fluorophenyl) - 1,3 - dihydroisobenzofuran - 5 -carbonitrile, is a drug which belongs to the group of specific serotonin reuptake inhibitors. It is used alone or in combination with other antidepressive and antipsychotic drugs to help treat a variety of psychiatric disorders (van Harten, 1993; Joffe et al., 1998; Mendez et al., 2005). Citalopram has shown efficacy in placebo-controlled clinical studies (Mendels et al., 1990) and has been marketed in several countries for the treatment of major depression (Mendoza et al., 2005). Citalopram is a fine, white powder that is sparingly soluble in water and soluble in ethanol. It is available as filmcoated, round or oval, white, scored tablets containing citalopram hydrobromide, corresponding to $10,20,30$ or $40 \mathrm{mg}$ of citalopram base in the Mexican market. Due to its safety and efficacy, it is widely available in Mexico.
Although several oral generic formulations of citalopram are available in Mexico, a MEDLINE search (1991-2007; key terms: bioequivalence, bioavailability, Mexico, and citalopram) failed to identify published data concerning the bioavailability of each formulation in the Mexican population. Thus, the aim of this study was to compare the bioavailability of one solid oral formulation of citalopram tablets $20 \mathrm{mg}$ with its corresponding listed drug reference in Mexico.

\section{Subjects, Materials and Methods}

\section{Study subjects}

For our study, a different set of eligible healthy Mexican adult subjects aged 18 to 55 years of either sex were recruited from an outpatient records taken from a database of the Centro de Estudios Científicos y Clínicos Pharma, S.A. de C.V. (Clinical unit), Mexico City, Mexico. All subjects provided written informed consent prior the commencement of the study. Thereafter, the subject's medical records were documented and a physical examination was conducted. Systolic and diastolic blood pressure (BP) was measured with a digital BP monitor (HEM-712C, Omron Healthcare, Vernon Hills, Illinois), which was previously calibrated. The BP cuff was applied to the right arm and the reading was taken in the sitting position. Inclusion eligibility was also based on successful completion of a clinical health evaluation, which consisted of a personal interview; a complete physical examination (BP, pulse, weight, temperature, and respiratory rate); diagnostic testing that included a 12-lead electrocardiogram and chest radiograph; a laboratory testing that included a complete blood cell count, metabolic and hepatic tests (alanine aminotransferase [reference range, 5-55 U/L], aspartate aminotransferase [5-34 U/L]), urianalysis, pregnancy test (for female subjects), blod chemistry for glucose (70-109 mg/dL), blood urea nitrogen $(7-23 \mathrm{mg} / \mathrm{dL})$, and creatinine $(0 .-1.3 \mathrm{mg} /$ $\mathrm{dL}$ ), as well as serologic tests for hepatitis (B and C), and HIV antibodies. Subjects were excluded if laboratory values were sig-

*Corresponding author: José Antonio Palma-Aguirre, Amores 320, Col. Del Valle, 03100 Mexico City, Mexico, E-mail: jpalma@cecycpharma.com

Received December 09, 2009; Accepted January 22, 2010; Published January 22, 2010

Citation: Palma-Aguirre JA, Mireya LG, de Jesus CST, Mariel PG, Elisa ZB, et al. (2010) Bioavailability of Two Oral Tablet Formulations of citalopram 20 mg: Single-Dose, Open-Label, Randomized, Two-Period Crossover Comparison in Healthy Mexican Adult Subjects. J Bioequiv Availab 2: 018-022. doi:10.4172/jbb.1000025

Copyright: (c) 2010 Palma-Aguirre JA, et al. This is an open-access article distributed under the terms of the Creative Commons Attribution License, which permits unrestricted use, distribution, and reproduction in any medium, provided the original author and source are credited. 
Citation: Palma-Aguirre JA, Mireya LG, de Jesus CST, Mariel PG, Elisa ZB, et al. (2010) Bioavailability of Two Oral Tablet Formulations of citalopram 20 mg: Single-Dose, Open-Label, Randomized, Two-Period Crossover Comparison in Healthy Mexican Adult Subjects. J Bioequiv Availab 2: 018-022. doi:10.4172/jbb.1000025

nificantly above or below the reference range and/or if all tests had not been performed. Testing was performed by Laboratorio de Análisis Clínicos LAPI, Salud Integral, S. A. de C. V. (Mexico City, Mexico), which has been certified by the Mexican government. In addition, the laboratory data were reviewed by the investigators of the clinical unit prior to the enrollment of the subjects. Subjects were compensated for participation.

For the study, 26 subjects were enrolled. Subject 15 did not allow participate into the study from the first period because he did not fulfill inclusion criteria. Subject 25 was withdrawn because he did not attend the appointment (due to personal reasons no related to any adverse event $[\mathrm{AE}]$ ), at the clinical unit for the second period of the study.

\section{Study design}

The protocol was approved by the ethics and research committee of the Centro de Estudios Científicos y Clínicos Pharma, S.A. de C.V. The study was carried out in accordance with the principles of the Declaration of Helsinki and its amendments (World Medical Association, 2008) and the International Conference on Harmonisation Guideline for Good Clinical Practice (59th WMA General Assembly, Seoul, October 2008).

A single-dose, randomized, open-label, 2-period crossover design was used. The subjects for the study arrived at the clinical site the day before the beginning of the study and were randomized in a 1:1 ratio using a table of random numbers to receive citalopram test formulation (Prepram ${ }^{\circledR}$ [Productos Medix, S. A. de C. V., Mexico City, Mexico]) followed by citalopram reference formulation $\left(\right.$ Seropram $^{\circledR}$, [Lundbeck México, S.A. DE C. V., Mexico City, Mexico]) or vice versa, with a 1-week washout period between doses. To obtain accurate baseline plasma measurements, subjects underwent a 12-hour overnight fast. Blood was drawn for baseline plasma measurements in the following manner: a 20-G catheter (Jelco ${ }^{\circledR}$ Plus, Medex Medical Ltd., Ascot, United Kingdom) was inserted in a suitable forearm vein and a 6-mL blood sample was drawn into a heparinized vacuum tube (Vacutainer ${ }^{\circledR}$, Becton, Dickinson and Company, Franklin Lakes, New Jersey). Before collection of each blood sample, $1 \mathrm{~mL}$ of blood was drawn from the catheter and discarded. After each blood sample was drawn, $0.5 \mathrm{~mL}$ of sodium heparin $(2.5 \mathrm{UI} / \mathrm{mL})$ was injected into the catheter to ensure patency. Subjects received a single 150-mg tablet of the study medication, given with $250 \mathrm{~mL}$ of water, and additional blood samples were drawn at $0.5,1.0,2.0,3.0,4.0,5.0,6.0,7.0,8.0$, $10.0,12.0,24.0,48.0,72.0,96.0$ y 120 hours after study drug administration. Plasma was obtained by centrifugation $(2000 \mathrm{~g}$ for 10 minutes at room temperature) and stored frozen at $-70^{\circ} \mathrm{C}$ until analyzed using high-performance liquid chromatography (HPLC). After a 1-week washout period, subjects returned to the clinical unit where the alternative formulation was administered and samples were drawn and analyzed as in the first treatment period.

\section{Determination of plasma citalopram concentrations}

Citalopram plasma levels were determined using HPLC assay method developed by personnel of Centro de Estudios Científicos y Clínicos pharma, S. A de C.V. Mexico City, Mexico. Briefly, $500 \mu \mathrm{L}$ of plasma, and $4 \mathrm{~mL}$ of ethyle acetate:dichloromethane $(75: 25 \mathrm{v} / \mathrm{v})$ were mixed by shaking in a glass test tube for 3 minutes. The tube was then centrifuged at $3500 \mathrm{rpm}$ for $7 \mathrm{~min}$ utes. The supernatant was frozen at $-70^{\circ} \mathrm{C}$ for 10 minutes, after removed and dried the organic phase, the extracts were reconstituted with $100 \mu \mathrm{L}$ of mobile phase and $25 \mu \mathrm{L}$ were injected into the chromatographic system. The separation of compounds was achieved on the column X Terra RP 18, 4.6 X 150mm, a precolumn (XDB C18 $4.6 \times 12.5 \mathrm{~mm}, 5 \mu \mathrm{m}$ ), $5 \mu \mathrm{m}$ and eluted with a mobile phase consisting of a trifluoroacetic acid solution $0.1 \% \mathrm{pH} 4.25 \pm 0.05$ : Acetonitrile $(66: 34 \% \mathrm{v} / \mathrm{v})$. The column temperature was environmental temperature. Flow rate was maintained constant at $0.8 \mathrm{~mL} / \mathrm{min}$, and detection was by fluorecsence detector at 249 wavelength. Under these conditions, the method was linear in the range of 4 to $200 \mathrm{ng} / \mathrm{mL}$ (Meng and Gauthier, 2005; Greiner et al., 2007). This method was considered suitable by the study investigators for pharmacokinetic studies of citalopram.

\section{Tolerability}

Tolerability was assessed by monitoring vital signs (blood pressure, heart rate, body temperature) at baseline, 4.5, 11.5, and 23.5 hours, and at the end of each period, laboratory analysis results, and subject interviews regarding the potential presence of adverse events (AEs) during the study.

\section{Pharmacokinetic and statistical analyses}

Using a power analysis $(\beta=0.2)$, it was determined that the power of the analysis of variance (ANOVA) was $>0.8$ at a $90 \%$ $\mathrm{CI}$, indicating that a total of 24 to 25 subjects would be sufficient for the purposes of each study. Individual plasma concentration-time curves were constructed; $\mathrm{C}_{\text {max }}$ and $\mathrm{T}_{\max }$ were directly obtained from these curves. AUC from time 0 (baseline) to 120 hours $\left(\mathrm{AUC}_{0-96}\right)$ was calculated using the trapezoidal rule (Chow and Liu, 2000; Chow and Liu, 2007). From the terminal logdecay phase, elimination rate constant $\left(\mathrm{k}_{\mathrm{e}}\right)$ was estimated using linear regression, and $\mathrm{t}_{1 / 2}$ was estimated using the following equation:

$$
\mathrm{t}_{1 / 2}=\ln 2 / \mathrm{k}_{\mathrm{e}}
$$

where $\ln$ was defined as the natural logarithm. Extrapolation of AUC from baseline to infinity $\left(\mathrm{AUC}_{0-\infty}\right)$ was calculated as follows:

$$
\mathrm{AUC}_{0-\infty}=\mathrm{AUC}_{0-120}+\left(\mathrm{C}_{120} / \mathrm{k}_{\mathrm{e}}\right)
$$

where $\mathrm{C}_{96}$ was defined as concentration at 120 hours.

To compare the bioavailability (in accordance with the criteria for bioequivalence [the rate and extent to which the active ingredient or active moiety is absorbed from a drug product and becomes available at the site of action] established by the US Food and Drug Administration, in vivo bioequivalence guidelines) of the formulations tested, an ANOVA for a 2 x 2 crossover design for $\ln$-transformed $\mathrm{C}_{\max }$, AUC from baseline to time $\mathrm{t}\left(\mathrm{AUC}_{0-\mathrm{t}}\right)$, and $\mathrm{AUC}_{0-\infty}$ was carried out for each study. Ratios of $\ln \mathrm{C}_{\text {max }}, \ln \mathrm{AUC}_{0-t}$, and $\ln \mathrm{AUC}_{0-\infty}$ for all formulations were calculated, and $90 \%$ CIs were obtained; ANOVA was performed using the F test. Probability of exceeding the limits of acceptance $(80 \%-125 \%)$ was obtained by the two 1 -sided $t$ tests described by Schuirmann (Schuirmann, 2007). The formulations were considered bioequivalent if the ln-transformed ratios of $\mathrm{C}_{\text {max }}$ and AUC were within the predetermined equivalence range of $80 \%$ to $125 \%$ and if $P$ was \pm 0.05 for the $90 \%$ CIs. All pharma- 


\section{Journal of Bioequivalence \& Bioavailability - Open Access \\ JBB/Vol.2 Issue 1}

cokinetic and statistical analyses were performed using WinNonlin version 5 (Pharsight, Mountain View, California).

\section{Results}

Twenty-five subjects were enrolled in the comparison between tablets of citalopram (16 men, 8 women; mean age, 26.92 years). Subjects in the study had the following demographics: age range, 18 to 50 years; mean weight of $64.04 \pm 8.78 \mathrm{~kg}$; and mean height of $1.67 \pm 0.09 \mathrm{~m}$; and mean body mass index of $23.10 \pm 1.74 \mathrm{~kg} /$ $\mathrm{m}^{2}$. Because the withdrawal of one subject, the sample size for the evaluation of the PK parameters for citalopram was reduced from 25 subjects to 24 subjects.

The bioequivalence test drug values were $\mathrm{C}_{\max }$ of $26.37 \pm 7.01$ $\mathrm{ng} / \mathrm{mL}, \mathrm{t}_{\max }$ of $3.76 \pm 1.61 \mathrm{~h}, \mathrm{AUC}_{0-\mathrm{t}}$ of $613.84 \pm 301.80 \mathrm{h.ng} /$ $\mathrm{mL}, \mathrm{AUC}_{0-\infty}$ of $879.65 \pm 417.28 \mathrm{~h} . \mathrm{ng} / \mathrm{mL}$, and reference drug values of $\mathrm{C}_{\max }$ of $25.50 \pm 7.76 \mathrm{ng} / \mathrm{mL}, \mathrm{t}_{\max }$ of $3.96 \pm 1.85 \mathrm{~h}$ $\mathrm{AUC}_{0-\mathrm{t}}$ of $596.65 \pm 325.61 \mathrm{~h} . \mathrm{ng} / \mathrm{mL}, \mathrm{AUC}_{0-\infty}$ of $982.38 \pm 527.44$ h. $\mathrm{ng} / \mathrm{mL}$. No period or sequence effect was observed.

\section{Pharmacokinetic parameters}

Mean and SD values of $\mathrm{C}_{\max }, \mathrm{AUC}_{0-96}$, and $\mathrm{AUC}_{0-\infty}$ for each formulation are shown in Table 1 and depicted in Figure 1. No period or sequence effects were observed for the pharmacokinetic properties in the ANOVA. In addition, there was no evidence of weight-related differences in individual AUC values and $\mathrm{C}_{\max }$ values. Table 2 shows the $90 \%$ CIs of the ratios (test/ reference) for the ln-transformed values of $\mathrm{C}_{\text {max }}$ (as an index of rate of absorption), $\mathrm{AUC}_{0-\mathrm{t}}$, and $\mathrm{AUC}_{0-\infty}$ (as an index of the extent of absorption); the probability of exceeding the limits of acceptance (Schuirmann's two 1-sided $t$ tests); and the power of the test for citalopram tablets (Schuirmann, 2007). The 90\% CIs for the corresponding ratios of $\mathrm{C}_{\max }, \mathrm{AUC}_{0-96}$, and $\mathrm{AUC}_{0-\infty}$ were within the $80 \%$ to $125 \%$ range. All $P$ values were $<0.05$. Similar results were found for data without a logarithmic transformation.

\section{Tolerability}

Thirteen volunteers reported at least one adverse event. Nausea and abdominal pain were the most common adverse events related with the study medication. Other adverse events were dry mouth, headache and increment in peristalsis. None of these required drug treatment.

\section{Discussion}

The results of our study suggest that the reference-test capsule formulations of citalopram were not statistically different in terms of their PK parameters ( $\mathrm{C}_{\max }$ and AUC). Considering that all $90 \%$ CIs of the ratios of the PK parameters $\left(\mathrm{C}_{\max }\right.$ and AUC) were found to be within the predetermined range (80\%-125\%) and the Schuirmann two one-sided $t$ test procedure (probability of exceeding limits of acceptance) found al probability values $<0.05$, the hypothesis that the estimated parameters exceeded limits of acceptance was rejected.

Based on the accepted regulatory requirements (COFEPRIS, NOM-177, 1998), this study suggests that the test formulation was bioequivalent to the reference formulation.

Al-Ghazawi and colleagues (Al-Ghazawi et al., 2007) reported a randomized crossover study conducted on 24 healthy Jordan

\begin{tabular}{|c|c|c|c|c|c|c|c|c|}
\hline \multirow{2}{*}{$\begin{array}{l}\text { Pharmacokineitc } \\
\text { paramter }\end{array}$} & \multicolumn{4}{|c|}{${\text { Reference Drug A }\left(\text { SEROPRAM }^{\circledR}\right)}^{\circledR}$} & \multicolumn{4}{|c|}{ Test Drug B (PREPRAM $\left.{ }^{\circledR}\right)$} \\
\hline & Mean & $\begin{array}{l}\text { Standard } \\
\text { Deviation }\end{array}$ & CV\% & $\mathbf{n}$ & Mean & $\begin{array}{l}\text { Standard } \\
\text { Deviation }\end{array}$ & CV\% & $\mathbf{N}$ \\
\hline $\mathrm{C}_{\max }(\mathrm{ng} / \mathrm{mL})$ & 25.50 & 7.76 & 30.43 & 24 & 26.37 & 7.01 & 26.58 & 25 \\
\hline $\mathrm{AUC}_{0-\mathrm{t}}$ (h. ng/mL) & 596.65 & 325.61 & 54.57 & 24 & 613.84 & 301.80 & 49.17 & 25 \\
\hline $\mathrm{AUC}_{0-\mathrm{Inf}}(\mathrm{h} . \mathrm{ng} / \mathrm{mL})$ & 982.38 & 527.44 & 53.69 & 24 & 879.65 & 417.28 & 47.44 & 25 \\
\hline $\mathrm{t}_{\max }(\mathrm{h})$ & 3.96 & 1.85 & 46.81 & 24 & 3.76 & 1.61 & 42.94 & 25 \\
\hline
\end{tabular}

Table 1 :

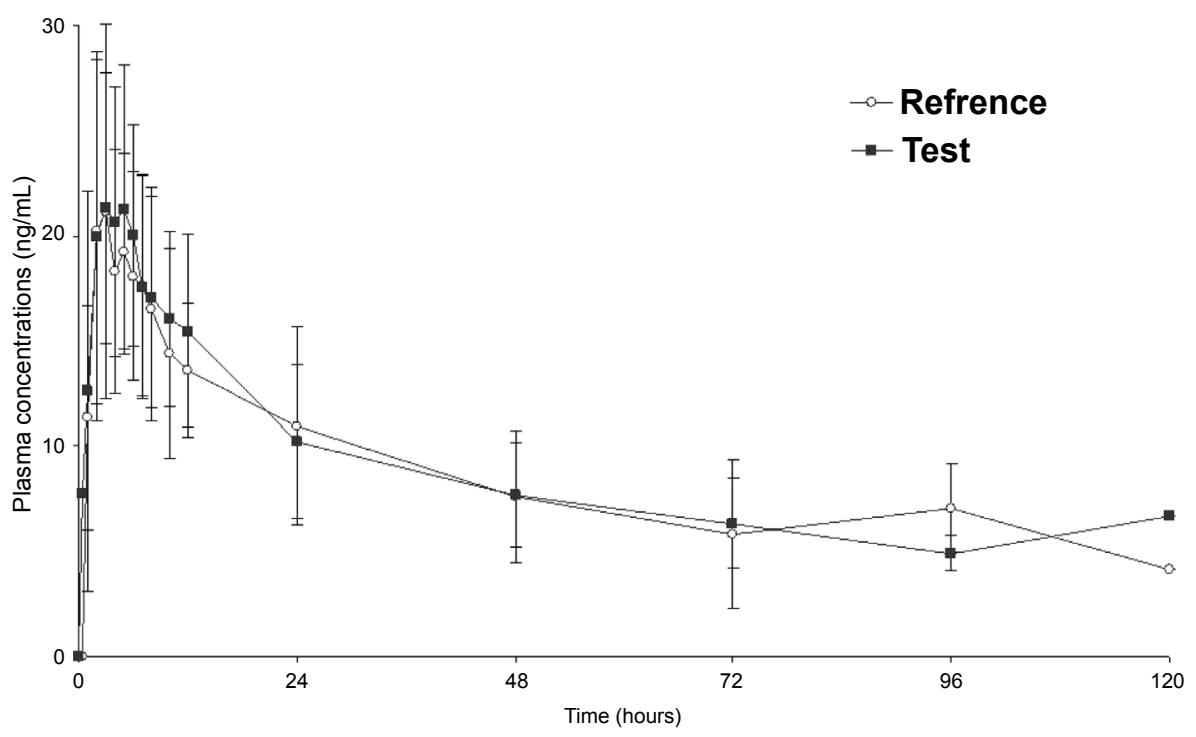

Figure 1: Mean plasma citalopram concentration-time curve for the test (Trademark: Prepram®, Drug B) and reference (Trademark: Seropram®, Drug A), oral tablet formulations of citalopram. 
Citation: Palma-Aguirre JA, Mireya LG, de Jesus CST, Mariel PG, Elisa ZB, et al. (2010) Bioavailability of Two Oral Tablet Formulations of citalopram $20 \mathrm{mg}$ : Single-Dose, Open-Label, Randomized, Two-Period Crossover Comparison in Healthy Mexican Adult Subjects. J Bioequiv Availab 2: 018-022. doi:10.4172/jbb.1000025

\begin{tabular}{|c|c|c|c|c|c|c|c|c|}
\hline $\begin{array}{l}\text { Pharmacokineitc } \\
\text { parameter }\end{array}$ & $\begin{array}{l}\text { Ratio \% } \\
\text { (Ref) }\end{array}$ & $\begin{array}{l}\text { CI 90\% } \\
\text { Clasiacal }\end{array}$ & $\begin{array}{c}\text { CI 90\% } \\
\text { Westlake }\end{array}$ & $\begin{array}{c}\text { Criteria for } \\
\text { accepting } \\
\text { Bioequivalence }\end{array}$ & $\begin{array}{c}\text { Two one- } \\
\text { sided } t \text { test } \\
\text { of } \\
\text { Schuirmann }\end{array}$ & p-value & Power & Conclusion \\
\hline $\begin{array}{l}\mathrm{LnCmax} \\
(\mathrm{ng} / \mathrm{mL})\end{array}$ & 105.36 & $\begin{array}{l}95.98- \\
115.65\end{array}$ & $\begin{array}{l}86.77- \\
113.23\end{array}$ & $80 \%-125 \%$ & $\begin{array}{c}\mathrm{P}(\mathrm{q}<80 \%)= \\
0.0000 \\
\mathrm{P}(\mathrm{q}>125 \%) \\
=0.0023\end{array}$ & $\mathrm{P}<0.05$ & 0.9872 & $\begin{array}{c}\text { Bio- } \\
\text { equivalente }\end{array}$ \\
\hline $\begin{array}{l}\text { LnAUC }_{0-\mathrm{t}} \\
\text { (h. ng/mL) }\end{array}$ & 101.12 & $\begin{array}{l}86.27- \\
118.53\end{array}$ & $\begin{array}{l}83.76- \\
116.24\end{array}$ & $80 \%-125 \%$ & $\begin{array}{c}\mathrm{P}(\mathrm{q}<80 \%)= \\
0.0094 \\
\mathrm{P}(\mathrm{q}>125 \%) \\
=0.0159\end{array}$ & $\mathrm{P}<0.05$ & 0.8 & $\begin{array}{c}\text { Bio- } \\
\text { equivalente }\end{array}$ \\
\hline
\end{tabular}

Table 2: Geometric mean ratios, $90 \%$ CIs of natural log-transformed data, the probability of exceeding the limits of acceptance ( $80 \%-125 \%$, and power test results of two oral formulations of citalopram after a single dose of $20 \mathrm{mg}$.

volunteers to compare the bioavailability of two formulations of citalopram $40 \mathrm{mg}$ tablets. The mean $\pm \mathrm{SD}$ maximum concentration of $\mathrm{C}_{\max }, \mathrm{AUC}_{0-\mathrm{t}}$ and $\mathrm{AUC}_{0-\infty}$ were $3.81 \pm 1.18$ and $33.4 \pm$ $7.80 \mathrm{ng} / \mathrm{ml}, 1,820 \pm 582$ and 1,660 $\pm 510 \mathrm{ng} . \mathrm{h} / \mathrm{ml}, 2,010 \pm 663$ and $1,850 \pm 577 \mathrm{microg} . \mathrm{h} / \mathrm{ml}$, for the test and reference drug, respectively. These values are similar to previously reported values in other ethnic groups, like volunteers from Czech Republic (Mendoza et al., 2005) German population (Gschwend et al., 2005), Brasilian people (Mendez et al., 2005) and Danish population (Joffe et al., 1998).

None of the reported AEs was considered serious by the investigators. Potential recall bias of AEs in this study was not likely because only one dose of each formulation was administered during each treatment period, subjects were under medical surveillance in the clinical unit, and the duration of the washout period was only 14 days.

\section{Limitations}

As with any clinical trial, and in particular for most bioavailability/bioequivalence studies, the current studies had some limitations that should be considered. First, this was an open-label study, so it might not objectively address the effectiveness and safety profiles of the formulations tested. Also, because the data were obtained from healthy subjects who were administered a single dose, the PK parameters of citalopram might differ in target populations.

In addition, this study was conducted under fasting conditions, because for bioequivalence studies is preferable the drug administration without food, however, to assess the food effect on the citalopram administration, further studies would be useful for a better characterization of its PK and bioavailability in Mexican population.

Due to the limited data, we are unable to predict the response to the drug at any time after administration of alternative doses and/or administration intervals. Further studies are needed to compare the test formulation efficacy and/or tolerability with the reference formulation in Mexican patient groups.

The results of this study may serve as a reference for future controlled studies of citalopram in the Hispanic population.

\section{Conclusions}

In this study in healthy Mexican adult subjects, a single dose of citalopram $20 \mathrm{mg}$ of the test formulation was found to be bioequivalent to the reference formulation according to the regu- latory definition of bioequivalence based on the rate and extent of absorption. All formulations were generally well tolerated.

\section{Acknowledgements}

The study was supported entirely by Laboratories Productos Medix S. A. de C. V., Mexico City, Mexico.

\section{References}

1. 59th WMA General Assembly, Seoul, October 2008 European Agency for the Evaluation of Medicinal Products (EMEA), International Conference on Harmonisation-World Health Organization. Guideline for Good Clinical Practice [EMEA Web site]. ICH Topic E6. Geneva, Switzerland: WHO; 2002. Available at: http://www.emeaeu.int. Accessed Mach 10, 2009. CrossRef » PubMed » Google Scholar

2. Chow SC, Liu JP (2000) Power and sample size determination. In: Design and Analysis of Bioavailability and Bioequivalence Studies. 2nd ed. New York, NY: Marcel Dekker 125-160. » CrossRef » PubMed » Google Scholar

3. Chow SC, Liu JP (2007) Statistical methods for average bioavailability. In: Design and Analysis of Bioavailability and Bioequivalence Studies. 2nd ed. New York, NY: Marcel Dekker 79-124. » CrossRef » PubMed » Google Scholar

4. Greiner C, Hiemke C, Bader W, Haen E (2007) Determination of citalopram and escitalopram together with their active main metabolites desmethyl (es) citalopram in human serum by column-switching high performance liquid chromatography (HPLC) and spectrophotometric detection. J Chromatogr B Analyt Technol Biomed Life Sci 848: 391-4. »CrossRef » PubMed » Google Scholar

5. Gschwend MH, Richter J, Sennewald R, Guserle R, Renner J, (2005) Bioavailability investigation of two different oral formulations of citalopram, a so-called 'second generation' antidepressant drug. Arzneimittelforschung 55: 730-7. » CrossRef » PubMed » Google Scholar

6. Joffe P, Larsen FS, Pedersen V, Ring-Larsen H, Aaes-Jørgensen T, et al. (1998) Single-dose pharmacokinetics of citalopram in patients with moderate renal insufficiency or hepatic cirrhosis compared with healthy subjects. Eur J Clin Pharmacol 54: 237-42. » CrossRef » PubMed » Google Scholar

7. Mendels J, Kiev A, Fabre LF (1999) Double-blind comparison of citalopram and placebo in depressed outpatients with melancholia. Depression and Anxiety 9: 54-60. » CrossRef » PubMed » Google Scholar

8. Mendes GD, Borges NC, Pereira Ados S, Mendes FD, Barrientos-Astigarraga RE, et al. (2005) A bioequivalence study of citalopram based on quantification by high-performance liquid chromatography coupled to electrospray tandem mass spectrometry. Int J Clin Pharmacol Ther 43: 38998. » CrossRef » PubMed » Google Scholar

9. Mendoza L, Hajdúch M, Kekulová H, Svobodová X, Mihál V, et al. (2005) Bioequivalence of two brands of citalopram $40 \mathrm{mg}$ tablets after single oral administration to healthy volunteers. Biomed Pap Med Fac Univ Palacky Olomouc Czech Repub 149: 169-72. »CrossRef » PubMed » Google Scholar

10. Meng QH, Gauthier D (2005) Simultaneous analysis of citalopram and desmethylcitalopram by liquid chromatography with fluorescence detec- 


\section{Journal of Bioequivalence \& Bioavailability - Open Access}

JBB/Vol.2 Issue 1

tion after solid-phase extraction. Clin Biochem 38: 282-5. » CrossRef » PubMed » Google Scholar

11. Ministry of Health of Mexico (2009) Federal Commission of Protection Against Sanitary Risks [COFEPRIS in Spanish] [Secretaria de Salud Web site]. Available at: http://www.salud.gob.mx. Accessed. »CrossRef » PubMed » Google Scholar
12. Schuirmann DJ (1987) A comparison of the two one-sided tests procedure and the power approach for assessing the equivalence of average bioavailability. J Pharmacokinet Biopharm 15: 657-680. »CrossRef » PubMed » Google Scholar

13. US Food and Drug Administration. In vivo bioequivalence guidances. Pharmacopeial Forum 19: 6501-6508. » CrossRef » PubMed » Google Scholar 